\title{
Effect Of Tune Up And Body Painting Motorcycle Training To Increase Trouble Solving Competency In Trenggalek
}

\author{
$1^{\text {st }}$ Andika Bagus Nur Rahma Putra \\ Mechanical Engineering, Faculty of Engineering \\ Universitas Negeri Malang \\ Malang, Indonesia \\ andika.bagus.ft@um.ac.id \\ $3^{\text {rd }}$ Amat Mukhadis \\ Mechanical Engineering, Faculty of Engineering \\ Universitas Negeri Malang \\ Malang, Indonesia \\ mukhadis_s@yahoo.com
}

\author{
$2^{\text {nd }}$ Sumarli \\ Mechanical Engineering, Faculty of Engineering \\ Universitas Negeri Malang \\ Malang, Indonesia \\ sumarli.ft@um.ac.id \\ $4^{\text {th }}$ Poppy Puspitasari \\ Mechanical Engineering, Faculty of Engineering \\ Universitas Negeri Malang \\ Malang, Indonesia \\ poppy.phd@gmail.com
}

\begin{abstract}
This research aims to perform the analysis: 1) percentage level of competence after training; 2) material that is considered difficult in training; and 3) factors causing the difficulty of increasing the competence of training tune ups and body painting motorcycles. This research uses qualitative method. The subject of research is the community of the workshop owner in the district of axis of the district of Trenggalek. Research subjects in the form of informants amounted to 20 people. This research shows: 1) percentage of competency level of engine system participants is 79,5\%; electrical system of $80.3 \%$; the chassis system of $80.9 \%$; and body painting system $80.2 \%$; 2) difficult materials include checking spark plugs, cleaning the carburetor, adjusting valves, checking electrical functions (buzzer, turn signal, headlight, material topic, checking steering wheel instability, and tightening bolts; 3) no training which is routinely related to the tune up and body painting of motorcycles facilities and infrastructure (tools) has not complied with standards and weak information related to the development of automotive technology.
\end{abstract}

Keywords-automotive training, tune-up, body-painting

\section{INTRODUCTION}

Indonesia has a pretty amazing development in the automotive world [1]. Not only this is mere but it is also supported by a handful of researchers who are doing analysis on the development of existing automotive in Indonesia. One is research conducted by Vijay Rao, Automotive and Transport Practice Frost \& Sullivan, which states that Indonesia is one of the largest automotive developments in ASEAN after Thailand [2]. Frost \& Sullivan predicts Indonesia will become the largest automotive market in ASEAN by 2019 with a total vehicle reaching 2.3 million [1]. Two-wheel motor vehicle. Population continues to swell from year to year. This happens because of the easiness of the community to own a motorcycle with various programs offered by manufacturers and finance companies.

On statistical data of Central Bureau of Statistics (last update December 5, 2014) can be seen improvement of motorcycle especially motorcycle. According to Chairman of the Indonesian Motorcycle Industry Association (AISI), Gunadi Shindhuwinata, the number of motorcycles in Indonesia is currently 85 million units [1]. Currently the incidence of motorcycles in Indonesia 85 million units. Of the total population of Indonesia which is approximately 250 millions, said one power three. According to him, motorcycles attracted the people of Indonesia because the price is affordable. Another phenomenon that makes sales of motorcycles is public transportation in the country that many people eat [3]. This condition is true contrary to the sales of motorcycles in producing countries, such as the United States, and Japan, where, people prefer to ride public transport.

Every year the number of vehicles in Indonesia is always increasing, According to the Head of Police Traffic Police Corps (Kakorlantas) Inspector General Police Agung Budi Maryoto, the population of vehicles in all parts of the archipelago reached 124,348,224 units [1]. This development is triggered by economic growth Stable Indonesia, increased class and increased investment in the automotive sector and enforcement of automotive regulations that support market growth. In addition to Vijay Rao, another researcher from the General Secretary of the Association of Indonesian Automotive Industries (Gaikindo), Noegardjito, also stated that his research at the National Automotive Industry Prospect Seminar Facing the ASEAN Economic Community (AEC) 2015 only sales about 100 thousand units or 7, 5\% and Indonesia's domestic sales growth may reach $23.6 \%$ per year [2]. In the seminar, he also stated in the competition with ASEAN countries with 
Thailand, Indonesia has an advantage on the type of motorcycle vehicle. But still weak for the type of sedan vehicle that is currently still controlled by Thailand, so he reinforce him and the team will participate in grabbing the ASEAN market because the automotive market in Indonesia is growing rapidly and become a driver for the market in the country is not pegged by outside products.

Excavating a wide range of potential terrain-will be endless. The abundance of natural resources and inexpensive human resources capabilities, making every region in Indonesia begin to grow rapidly and show its superiority in each sector. No exception strikes the local businessmen in Trenggalek regency, East Java which began to show its existence in the local market, national, even to penetrate the international market. Trenggalek regency itself is one of the mountains located in the southern part of East Java Province. W ith an area of about 126,140 hectares, Trenggalek regency is divided into 14 districts and 157 villages with a total population of 691,295 in 2016 [1]. This area has hundreds of SMEs scattered in various sub districts or villages with various kinds of commodity products that can not be underestimated.

One of the trends is the business of motorcycle painting workshops. Particularly in Kampak sub district that has a population of 38,794 people [4]. The amount is fairly large with an area of only $77.14 \mathrm{~km} 2$. The sub-district consists of 7 villages with an average population of six thousand inhabitants. The increasing number of motorcycle users in this sub district is the need for motorcycle service [2]. Initial observations made by the research team (January, 2017) and observations (March, 2017) resulted from less than 10 motorcycle workshops in the sub-district with fairly low HR standards. In addition, preliminary observations and observations also explain the average total damage to motorcycles in the sub district is quite large.

\section{METHOD}

This research uses qualitative method. The research subject is the community of the workshop owner in Kampak Subdistrict of Trenggalek Regency. Research subjects in the form of informants amounted to 20 people who participated in training tune up and body painting motorcycles. Data collection techniques with observation, interviews, and documentation. Form of data obtained in the form of the level of competence of each person after training Tune Up and Body Painting motorcycle. In addition, data also obtained percentage of difficulty level of training materials Tune Up and Body Painting motorcycles, factors causing the difficulty of increasing the competence of Tune Up and Body Painting motorcycles, as well as the level of motivation of trainees Tune Up and Body Painting motorcycles. In detail described in Fig. 1.

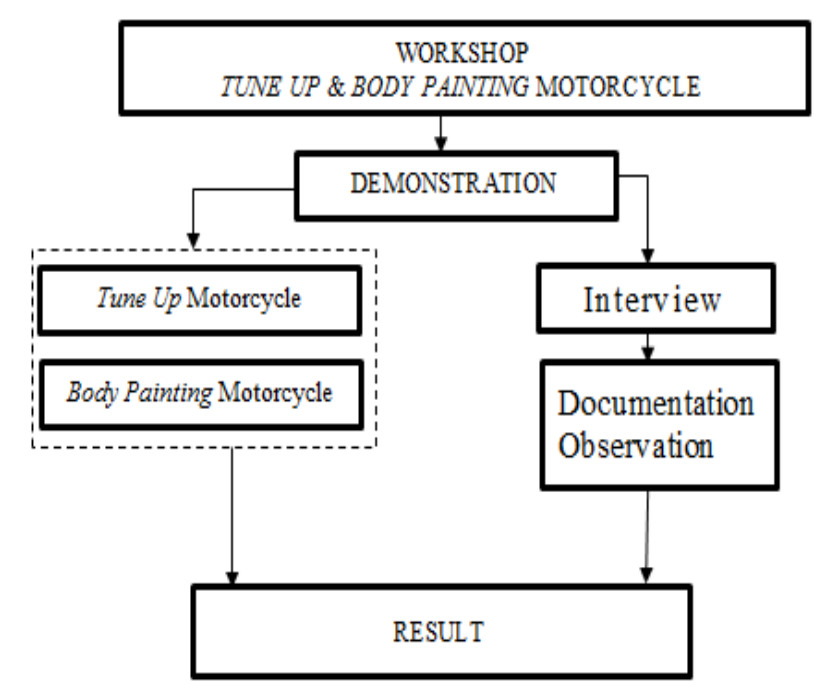

Fig. 1. Research Design

T ABLE I. CONTENT OF SKILL

\begin{tabular}{|c|c|c|}
\hline No. & Material (skill) & Topic \\
\hline \multirow[t]{8}{*}{1} & \multirow[t]{8}{*}{ Machine System } & Checking and replacing engine lubricant oil \\
\hline & & Cleaning the air filter \\
\hline & & Clean the fuel filter \\
\hline & & Check and adjust the spark plug \\
\hline & & Cleaning the carburetor \\
\hline & & Set the valve \\
\hline & & Set fuel mix/engine speed \\
\hline & & Sets the clutch \\
\hline \multirow[t]{2}{*}{2} & \multirow[t]{2}{*}{ Electrical System } & Checking and maintaining the battery \\
\hline & & $\begin{array}{l}\text { Check the electrical functions (bell, turn signal, } \\
\text { lights }\end{array}$ \\
\hline \multirow[t]{5}{*}{3} & \multirow[t]{5}{*}{ Chassis System } & Check and set brake free motion \\
\hline & & Check, maintain and adjust wheel-free motion \\
\hline & & Check the shaft steering \\
\hline & & Check the tire condition and adjust tire pressure \\
\hline & & Check and tighten the bolts (bolt \\
\hline \multirow[t]{5}{*}{4} & \multirow{5}{*}{$\begin{array}{l}\text { Body Painting } \\
\text { Motorcycles }\end{array}$} & Sanding technique \\
\hline & & Semi-dying early \\
\hline & & Basic Painting Technique \\
\hline & & Color Mixing Technique \\
\hline & & Color Manipulation T echnique \\
\hline
\end{tabular}

As the result of the total analysis of the problems of the partners above, then to solve the problems encountered indepth study of the solution will be done. This is by doing the theory of tune-up motorcycle and Conducting the body painting theory of motorcycle.

\section{RESULTS}

In this chapter, we will review four main study results, including: percentage of competency level of participants after TuneUp training and Body Painting of motorcycles, percentage of difficulty level of TuneUp training materials and Body Painting of motorcycles, and factors causing the difficulty of increasing Tune Up competence and Body Painting motorcycle 
T ABLE II PERCENTAGE OF COMPETENCY LEVEL OF PARTICIPANTS AFTER TRAINING

\begin{tabular}{|c|c|c|c|c|}
\hline \multirow{2}{*}{$\begin{array}{c}\text { No. } \\
\text { Parti- } \\
\text { cipants }\end{array}$} & \multicolumn{4}{|c|}{ The Value of Understanding of Training Results } \\
\cline { 2 - 5 } & $\begin{array}{c}\text { Engine } \\
\text { System }\end{array}$ & $\begin{array}{c}\text { Eectrical } \\
\text { System }\end{array}$ & $\begin{array}{c}\text { Chassis } \\
\text { System }\end{array}$ & $\begin{array}{c}\text { Body } \\
\text { Painting }\end{array}$ \\
\hline 1 & $78 \%$ & $84 \%$ & $78 \%$ & $86 \%$ \\
\hline 2 & $80 \%$ & $82 \%$ & $80 \%$ & $88 \%$ \\
\hline 3 & $68 \%$ & $78 \%$ & $80 \%$ & $76 \%$ \\
\hline 4 & $88 \%$ & $96 \%$ & $82 \%$ & $76 \%$ \\
\hline 5 & $76 \%$ & $72 \%$ & $94 \%$ & $92 \%$ \\
\hline 6 & $92 \%$ & $82 \%$ & $94 \%$ & $88 \%$ \\
\hline 7 & $78 \%$ & $88 \%$ & $78 \%$ & $82 \%$ \\
\hline 9 & $82 \%$ & $88 \%$ & $86 \%$ & $84 \%$ \\
\hline 10 & $94 \%$ & $86 \%$ & $86 \%$ & $70 \%$ \\
\hline 11 & $88 \%$ & $88 \%$ & $94 \%$ & $86 \%$ \\
\hline 12 & $86 \%$ & $96 \%$ & $96 \%$ & $82 \%$ \\
\hline 13 & $78 \%$ & $80 \%$ & $82 \%$ & $88 \%$ \\
\hline 14 & $90 \%$ & $84 \%$ & $90 \%$ & $84 \%$ \\
\hline 15 & $90 \%$ & $82 \%$ & $82 \%$ & $90 \%$ \\
\hline 16 & $78 \%$ & $84 \%$ & $84 \%$ & $90 \%$ \\
\hline 17 & $90 \%$ & $86 \%$ & $80 \%$ & $90 \%$ \\
\hline 18 & $86 \%$ & $80 \%$ & $82 \%$ & $98 \%$ \\
\hline 19 & $84 \%$ & $80 \%$ & $78 \%$ & $82 \%$ \\
\hline 20 & $84 \%$ & $90 \%$ & $92 \%$ & $72 \%$ \\
\hline Average & $79,5 \%$ & $80,3 \%$ & $80,9 \%$ & $80,2 \%$ \\
\hline
\end{tabular}

From Table II it can be interpreted that the average percentage of competency level of participants after attending training of motorcycle tune-up and body painting above $75 \%$. In detail each average of each material is: system engine of $79.5 \%$; electrical system of $80.3 \%$; the chassis system of $80.9 \%$; and body painting system of $80.2 \%$. On the whole the participants (20 people) the smallest percentage of $72 \%$. On the whole the participants ( 20 people) the smallest percentage of $98 \%$.

T ABLE III. PERCENTAGE OF DIFFICULTY LEVEL OF TRAINING MATERIALS IN ENGINE SYSTEM

\begin{tabular}{|l|l|c|c|}
\hline \multirow{2}{*}{ No. } & \multicolumn{1}{|c|}{ Topic } & \multicolumn{2}{c|}{ Percent of Answer } \\
\cline { 3 - 4 } & & True & False \\
\hline 1 & $\begin{array}{l}\text { Checking and replacing } \\
\text { engine lubricant oil }\end{array}$ & $80 \%$ & $20 \%$ \\
\hline 2 & Cleaning the air filter & $85 \%$ & $15 \%$ \\
\hline 3 & Clean the fuel filter & $80 \%$ & $20 \%$ \\
\hline 4 & $\begin{array}{l}\text { Check and adjust the spark } \\
\text { plug }\end{array}$ & $40 \%$ & $60 \%$ \\
\hline 5 & Cleaning the carburetor & $45 \%$ & $55 \%$ \\
\hline 6 & Set the valve & $45 \%$ & $55 \%$ \\
\hline 7 & Set fuel mix / engine speed & $70 \%$ & $30 \%$ \\
\hline 8 & Sets the clutch freedom & $90 \%$ & $10 \%$ \\
\hline
\end{tabular}

In Table III it can be interpreted that there are 3 topics/materials on the engine system that are considered difficult (percentage below 50\%). The material is to check the spark plugs, clean the carburetor, and set the valve. While as many as 5 topics/materials that have a percentage value above $50 \%$. The material is to check and change the engine lubricant oil, clean the air filter, clean the fuel filter, adjust the fuel mix/spin machine, and set the freedom of the clutch.
T ABLE IV. PERCENTAGE OF DifFICULTY LEVEL OFTRAINING MATERIALS IN ELECTRICAL SYSTEM

\begin{tabular}{|l|l|c|c|}
\hline \multirow{2}{*}{ No. } & \multicolumn{1}{|c|}{ Topic } & \multicolumn{2}{|c|}{ Percent of Answer } \\
\cline { 3 - 4 } & & True & False \\
\hline 1 & $\begin{array}{l}\text { Checking and maintaining } \\
\text { the battery }\end{array}$ & $95 \%$ & $5 \%$ \\
\hline 2 & $\begin{array}{l}\text { Check the electrical } \\
\text { functions (bell, turn signal, } \\
\text { lights }\end{array}$ & $45 \%$ & $55 \%$ \\
\hline
\end{tabular}

In Table IV it can be interpreted that the percentage of difficulty level of Tune Up training materials and Body Painting motorcycles. On the topic / material checking and care for batteries obtained percentage of participants answered correctly by $95 \%$. While the percentage of participants answered wrong, by 5\%. On the topic / material check the electrical function (bell, turn sign lights, and headlights) got the percentage of participants answered correctly by $45 \%$. While the percentage of participants answered wrong by $55 \%$.

T ABLE V. PERCENTAGE OF DIFFICULTY LEVEL OF TRAINING MATERIALS IN CHASSIS SYSTEM

\begin{tabular}{|l|l|c|c|}
\hline No. & \multicolumn{1}{|c|}{ Topic } & \multicolumn{2}{c|}{ Percent of Answers } \\
\cline { 3 - 4 } & & True & False \\
\hline 1 & $\begin{array}{l}\text { Check and set brake free } \\
\text { motion }\end{array}$ & $85 \%$ & $15 \%$ \\
\hline 2 & $\begin{array}{l}\text { Check, maintain and adjust } \\
\text { wheel-free motion }\end{array}$ & $70 \%$ & $30 \%$ \\
\hline 3 & Check the shaft steering & $40 \%$ & $60 \%$ \\
\hline 4 & $\begin{array}{l}\text { Check the tire condition and } \\
\text { adjust tire pressure }\end{array}$ & $75 \%$ & $25 \%$ \\
\hline 5 & Check and tighten the bolts & $45 \%$ & $55 \%$ \\
\hline
\end{tabular}

In Table $\mathrm{v}$ it can be interpreted that there are 2 topics/materials that have a true percentage of answers below $50 \%$, the material includes Checking the steering wheel instability and tightening the bolts. In addition, there are 3 topics/materials that have a percentage of correct answers above $50 \%$, the material includes Checking and setting brake free motion, Checking, maintaining and adjusting wheel-free motion, Checking the tire condition and adjusting the tire's wind pressure

T ABLE VI. PERCENTAGE OFDIFFICULTY LEVEL OFTRAINING MATERIALS IN BODY PAINTING

\begin{tabular}{|l|l|c|c|}
\hline \multirow{2}{*}{ No. } & \multicolumn{1}{|c|}{ Topic } & \multicolumn{2}{|c|}{ Percent of Answer } \\
\cline { 3 - 4 } & & True & False \\
\hline 1 & Sanding technique & $80 \%$ & $20 \%$ \\
\hline 2 & Semi-dying early & $45 \%$ & $55 \%$ \\
\hline 3 & Basic Painting Technique & $65 \%$ & $35 \%$ \\
\hline 4 & Color Mixing Technique & $60 \%$ & $40 \%$ \\
\hline 5 & Sanding technique & $40 \%$ & $60 \%$ \\
\hline
\end{tabular}

Table VI shows that there are 2 topics/materials that have a true percentage of answers below 50\%, the material includes the initial semi-dying and color manipulation techniques. On the other hand, there are 3 topics. The material has the correct answer value above $50 \%$. Such materials include the technique 
of sanding, basic painting techniques, and color mixing techniques.

T ABLE VII. INTERVIEW ANALYSIS RESULT

\begin{tabular}{|l|l|c|c|}
\hline \multirow{2}{*}{ No. } & \multicolumn{1}{|c|}{ Topic } & \multicolumn{2}{c|}{ Percent of Answer } \\
\cline { 3 - 4 } & & True & False \\
\hline 1 & $\begin{array}{l}\text { Workshop tune up the } \\
\text { motorcycle periodically }\end{array}$ & $35 \%$ & $65 \%$ \\
\hline 2 & $\begin{array}{l}\text { Body painting workshop } \\
\text { motorcycle periodically }\end{array}$ & $40 \%$ & $60 \%$ \\
\hline 3 & $\begin{array}{l}\text { Attended workshop tune up } \\
\text { and body painting outside the } \\
\text { city }\end{array}$ & $25 \%$ & $75 \%$ \\
\hline 4 & $\begin{array}{l}\text { Completeness of facilities } \\
\text { and infrastructure (tool) } \\
\text { motorcycle service }\end{array}$ & $60 \%$ & $40 \%$ \\
\hline 5 & $\begin{array}{l}\text { Facilities and infrastructure } \\
\text { tools) meets the standards }\end{array}$ & $35 \%$ & $65 \%$ \\
\hline 6 & $\begin{array}{l}\text { Substitution of facilities and } \\
\text { infrastructure(tools) on a } \\
\text { regular basis }\end{array}$ & $45 \%$ & $55 \%$ \\
\hline 7 & $\begin{array}{l}\text { Update the latest information } \\
\text { about tune up and body } \\
\text { painting motorcycles }\end{array}$ & $70 \%$ & $30 \%$ \\
\hline 8 & $\begin{array}{l}\text { Always read media } \\
\text { information such as } \\
\text { magazines and automotive } \\
\text { newspapers }\end{array}$ & $30 \%$ & $70 \%$ \\
\hline 9 & $\begin{array}{l}\text { Reconstruction information } \\
\text { technology }\end{array}$ & $40 \%$ & $60 \%$ \\
\hline & \multicolumn{2}{|l}{} \\
\hline
\end{tabular}

Contents Table VII explains that there are 2 questions topics that have a percentage value above 50\%. Topic questions include Completeness of facilities and equipment (tool) motorcycle service and Update the latest information about the tune up and body painting motorcycle. In addition, there are 7 question topics that have a percentage value above $50 \%$. Topic questions include Workshop tune up motorcycle, periodical, Body painting workshop periodic motorcycle, Following the workshop tune up and body painting outside the city, and Facilities and infrastructure (tool) meets the standards.

\section{DISCUSSION}

\section{A. Improved Competence Pre-Workshop}

Training is an activity designed to develop human resources through a series of identified activities, as ses sment and learning processes [3]. This is done through efforts to help develop the skills necessary to carry out the tasks, both now and in the future. In the training of tune-up and body painting of motorcycles, the increase of competency is significant. It can be seen that the average value of understanding of the participants' training results is $80 \%$. From that training then tune up training and body painting motorcycles can improve competence of participants.

Training tune up and body painting of motorcycles that include chassis system, body painting, system engine, electrical system provide participants experience in solving real problems [1]. Through training, the brain will be forced to do real construction. In addition, through training, participants gain skills in order to achieve effectiveness in performing certain tasks through the development of thinking processes, attitudes, knowledge, skills and abilities. Training is emphasized to improve the performance of trainees in carrying out the task [1]. Training as part of an education that contains learning to acquire and improve skills, a relatively short time and a method that prioritizes practice rather than theory.

\section{B. The difficulty level of training materials}

In the training tune up and body painting motorcycles there are materials that are difficult to master the participants. The material is a material that has a complex problem solving level. In material system engine, material topics that are considered difficult include checking the spark plugs, cleaning the carburetor, and setting the valve. In the material electrical system that is the topic of material check the electrical function (bell, turn sign lights, and head lamp. In the material chassis system includes the topic material Check the shaft steering wheeziness and tightening the bolts binding. In body painting material cover material topic semi-dying initial and color manipulation techniques.

The low percentage on the topic matter above is due to the study of every material topic that is full and thorough. It makes the brain experience regeneration rate thought yank slowed slightly [5]. It causes brain power in digesting and analyzing less than optimal problems. In addition, for example on the topic of color manipulation techniques, the level of the brain's imagination is needed [4]. Other examples of material topics examine electrical functions that require participants to analyze and diagnose each component of the electrical system in detail. On the other hand, the participants' initial understanding is necessary to avoid misconceptions in solving the problem.

\section{Factors Causing Difficulty in Mastering Training \\ Materials}

Based on the results analysis, factors causing the difficulty of participants in the mastery of training materials include 1) no training conducted routinely related to tune up and body painting motorcycles; 2) facilities and equipment (tools) not yet in accordance with standards; and 3) weak information related to the development of automotive technology.

D. No Training Is Conducted Routinely Related To Tune Up And Body Painting Motorcycle

Training aims to improve the mastery of various skills and techniques of specific, detailed and routine work execution. The training was able to develop the performance of the mindset of the brain in solving new problems [6]. Based on the results of interviews on the participants, it can be explained that the training is still not good about tune up and body painting motorcycles. In addition, participants were also less enthusiastic about the training they had ever attended. This is a big loss because training can work to increase knowledge, especially the latest discoveries in the field of science concerned. On the other hand, the development of the automotive world is increasing and must continue to be studied [7].

Regular training periodically aims at the process of updating information that has been stored in the brain. It keeps 
the brain growing with new and relevant information. The brain will have a high degree of problem solving if the substance that is digested by the brain also increases [6]. Not only that, the training provides many new experiences that have never before been saved by the brain. Experience that includes real problems with the various conditions presented by the current phenomenon.

\section{E. Facilities And Infrastructure (Tools) Have Not Complied With The Standards}

Completeness of facilities and infrastructure (tools) in the workshop is the key to successful management of the workshop. Vehicle service equipment especially motorcycle vehicle has a high level of accuracy. The tool should be able to be used properly so as to reduce the risk of error in service of the vehicle [1]. Risks include damage and wear and tear of motorcycle components due to the tools used are not compliant with the standard. It will have a direct impact on the quality of motorcycle parts repairs. In addition, nonstandard repair tools will make the user have difficulty in working on vehicle repairs.

Facilities and infrastructure (tools) at the time of repair need to be replaced with new tools on a regular basis [8]. The average use of the tool is adjusted to the level of frequent use. In the training of tune up and body painting motorcycles, participants have difficulty in mastering the material because they are still not used to using new tools. It will hamper the increase of individual competence. Competence is able to develop quickly if the brain already has good initial information.

\section{F. Weak Information On The Development Of Automotive Technology}

The development of the world automotive world continues to increase with various technologies. It directly affects the level of ability of everyone in the operation of the vehicle. The ever-increasing development should be confronted with the increased absorption of information related to the new technology [7]. The growing automotive world, the growing all the vehicles. On the other hand, the problem is also more complex. Therefore, the competence should also continue to be improved in order to solve any new problems that arise on the vehicle [6].

Updating information can be through reading, attending seminars, or discussing with experts. The easiest thing is done one of them by reading electronic media and print media. Electronic media can respond more quickly to every world automotive development [1]. The results of the interview analysis on the participants, indicating that they are less updated in processing new information. It directly makes it difficult to master the material on tune up training and body painting of motorcycles. Reconstruction of information on the brain increases with the information it receives. Systematically, the brain will have a wide memory if it continues to get new knowledge stimulus.

\section{CONCLUSION}

First, the percentage competency level of system engine participants is $79,5 \%$; electrical system of $80.3 \%$; the chassis system of $80.9 \%$; and body painting system of $80.2 \%$. Second, the material that is considered difficult include checking the spark plugs, cleaning the carburetor, adjusting the valve, checking the electrical functions (bell, turn signal, headlight, material topic, checking the shaft steering, and tightening the bolts bolt. Third, no training which is routinely related to the tune up and body painting of motorcycles facilities and infrastructure (tools) has not complied with standards and weak information related to the development of automotive technology.

\section{REFERENCES}

[1] A. B. N. R. Putra, W. Irdianto, A. Mukhadis, and S. Suhartadi, "Pocket Book Learning: Learning Methods to Train Students Productive and Creative Using 'BRANO' as an Effective Learning Recorder," in Proceedings of the International Mechanical Engineering and Engineering Education Conferences (IMEEEC-2016), 2016, vol. 30034, p. 30034.

[2] A. B. N. R. Putra, A. Mukhadis, and S. Suhartadi, "Miskonsepsi Transmisi Mobil dan Pemecahannya Menggunakan Pembelajaran Peta Pikiran pada Kompetensi Memelihara Transmisi Mobil Siswa SMK," Teknol. dan Kejuru., vol. 38, no. 2, pp. 133-146, 2016.

[3] H. Suswanto, A. M. Nidhom, A. B. N. R. P. Putra, and J. A. H. Hammad, "Developing An LMS-Based Cross-Platform Web Application For Improving Vocational High School Students' Competitiveness In ASEAN Economic Community," Pendidik. Sains, vol. 5, no. 3, pp. 72-79, 2017.

[4] A. Pandriana, N. Sumarna, and R. A. M. Noor, "STUDI EKSPLORASI SARANA PRASARANA PRAKTIK DAN MOTIVASI BELAJAR SISWA SMK," J. Mech. Eng. Educ., vol. 4, no. 1, pp. 1-5, 2017.

[5] F. Rahman, D. Supriawan, and T. Permana, "STUDI EKSPLORASI FASILITAS WORKSHOP TEKNIK OTOMOTIF SMK NEGERI 2 GARUT BERDASARKAN STANDAR SARANA PRASARANA," J. Mech. Eng. Educ., vol. 2, no. 1, pp. 39-47, 2015.

[6] T. M. Habeahan, I. H. Kusumah, and U. Karo-Karo, "STUDI TENTANG KETERSEDIAAN FASILITAS WORKSHOP OTOMOTIF SMKN 8 BANDUNG BERDASARKAN STANDARSARANA PRASARANA PENDIDIKAN NASIONAL UNTUK MEMENUHI STANDAR UJI KOMPETENSI," J. Mech. Eng. Educ., vol. 2, no. 2, pp. 293-299, 2015.

[7] M. N. Dassi, A. Gaudin, Z. Abbadi, L. Gagliardini, C. Pézerat, and F. Gautier, "ANALYSIS OF THE PERFORMANCES OF AUTOMOTIVE CAR BODIES WITH DIFFERENT STRUCTURAL CONTRASTS,” pp. 7-10, 2015.

[8] A. B. N. R. Putra and P. Puspitasari, "Effect of Diameter Hole Size Main Jet on Performance and Emissions on the Use of Fuel Liquid Petroleum Gas (LPG)," in International Conference on Electrical Engineering, Informatics, and Its Education, 2015, no. 1, pp. 12-18. 